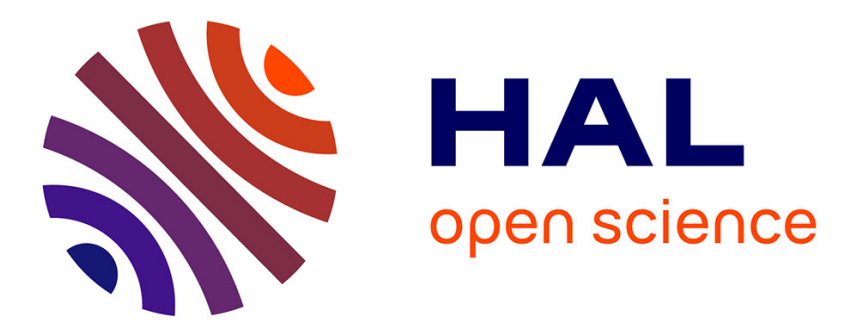

\title{
Formaldehyde in cultivated mushrooms: a negligible risk for the consumer
}

\author{
Wendie Liliane Claeys, Christiane Vleminckx, Alain Dubois, André \\ Huyghebaert, Monica Höfte, Paul Daenens, Bruno Schiffers
}

\section{To cite this version:}

Wendie Liliane Claeys, Christiane Vleminckx, Alain Dubois, André Huyghebaert, Monica Höfte, et al.. Formaldehyde in cultivated mushrooms: a negligible risk for the consumer. Food Additives and Contaminants, 2009, 26 (09), pp.1265-1272. 10.1080/02652030903081929 . hal-00573893

\section{HAL Id: hal-00573893 https://hal.science/hal-00573893}

Submitted on 5 Mar 2011

HAL is a multi-disciplinary open access archive for the deposit and dissemination of scientific research documents, whether they are published or not. The documents may come from teaching and research institutions in France or abroad, or from public or private research centers.
L'archive ouverte pluridisciplinaire HAL, est destinée au dépôt et à la diffusion de documents scientifiques de niveau recherche, publiés ou non, émanant des établissements d'enseignement et de recherche français ou étrangers, des laboratoires publics ou privés. 


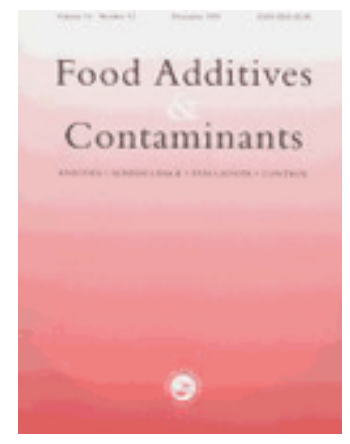

\section{Formaldehyde in cultivated mushrooms: a negligible risk for the consumer}

\begin{tabular}{|r|l|}
\hline Journal: & Food Additives and Contaminants \\
\hline Manuscript ID: & TFAC-2008-431.R1 \\
\hline Manuscript Type: & Review \\
\hline Date Submitted by the & $12-$ May-2009 \\
\hline Complete List of Authors: & $\begin{array}{l}\text { Claeys, Wendie; FASFC, Policy Control } \\
\text { Vleminckx, Christiane; Scientific Institute of Public Health } \\
\text { Dubois, Alain; Federal Agency for the Safety of the Food Chain } \\
\text { Huyghebaert, André; Ghent University } \\
\text { Höfte, Monica; Ghent University } \\
\text { Daenens, Paul; Catholic University Leuven } \\
\text { Schiffers, Bruno; Gembloux Agricultural University }\end{array}$ \\
\hline Methods/Techniques: & HPLC \\
\hline Fdditives/Contaminants: & Natural toxicants, Pesticide residues \\
\hline Food Types: & Mushrooms \\
\hline
\end{tabular}

\section{SCHOLARONE ${ }^{\text {MT }}$ Manuscripts}


1 FORMALDEHYDE IN CULTIVATED MUSHROOMS: A NEGLIGIBLE RISK FOR THE 2 CONSUMER

3

4

5 Wendie Claeys ${ }^{1}$, Christiane Vleminckx ${ }^{2}$, Alain Dubois ${ }^{1}$, André Huyghebaert ${ }^{3}$, Monica Höfte ${ }^{3}$, 6 Paul Daenens ${ }^{4}$ and Bruno Schiffers ${ }^{5}$

7

8

$9 \quad{ }^{1}$ Federal Agency for the Safety of the Food Chain, Brussels, Belgium

$10{ }^{2}$ Scientific Institute of Public Health, Brussels, Belgium

$11{ }^{3}$ Ghent University, Ghent, Belgium

$12{ }^{4}$ Catholic University Leuven, Leuven, Belgium

$13{ }^{5}$ Gembloux Agricultural University, Gembloux, Belgium 


\section{Abstract}

15 Following the detection of formaldehyde in cultivated mushrooms, an evaluation was carried out 16 to asssess whether its presence in food poses a risk to public health. Formaldehyde, a 17 carcinogenic chemical, has a broad range of industrial applications and hence, exposure to 18 formaldehyde is ubiquitous through diverse consumer goods, food, the air, etc. The observed 19 levels of formaldehyde in mushrooms are lower than the levels that are reported for vegetables, 20 fruit, meat, fish and dairy products. On the basis of available data, a rough estimate of the 21 dietary exposure to formaldehyde was performed. The exposure through the consumption of 22 cultivated mushrooms ( $\sim 0.19 \mu \mathrm{g} / \mathrm{kg}$ bw per day on average, consumers only) appeared to be 23 small compared to the total dietary intake of formaldehyde $(\sim 99.0 \mu \mathrm{g} / \mathrm{kg} \mathrm{bw}$ per day, total 24 population). Based on comparison with toxicological safety limits for chronic exposure and given 25 that formaldehyde is carcinogenic only through inhalation and not by ingestion, it can be 26 concluded that the dietary exposure to formaldehyde is not a cause for concern.

27

28 29 30

31 Keywords: formaldehyde, food, mushrooms, exposure 


\section{Introduction}

Formaldehyde $\left(\mathrm{CH}_{2} \mathrm{O}\right.$, CAS $\left.50-0-0\right)$ is a colourless, flammable gas that is commercially available as a $35-40 \%$ aqueous solution (formalin), as formol (a mixture of formaldehyde, formic acid and methanol in water) or as the precursor hexamethylenetetramine (a complex of formaldehyde with ammonium). In the solid form formaldehyde is available as the trimer trioxane $\left(1,3,5\right.$-trioxane or s-trioxane) or as the polymer paraformaldehyde $\left((\mathrm{CH} 2 \mathrm{O})_{n}\right.$ with $\left.n \geq 8\right)$ (IPCS 1989, 2002).

Formaldehyde is classified by the "International Agency on Cancer" (IARC) into Group 1, carcinogenic to humans (IARC 2006). Within the EU formaldehyde is currently classified as a category 3 carcinogen with the risk phrase 'R40, limited evidence of a carcinogenic effect' (Directive 2001/59/EC), but discussions are currently taking place to change this classification to category 1 - 'R49, may cause cancer by inhalation'. Most studies regarding the toxicity of formaldehyde relate to the inhalation of formaldehyde, which is probably the most important route of exposure. The available data on the effects of ingestion or of skin contact with formaldehyde are limited. Since formaldehyde is water soluble, highly reactive with biological macromolecules (formaldehyde induces DNA-protein and protein-protein cross-links) and rapidly metabolized, the effects of exposure are mainly observed in those tissues or organs which come into first contact with formaldehyde, namely the respiratory and gastrointestinal tract, oral and gastro-intestinal mucosa included (erosion, ulceration, inflammation and hyperplasia of stomach and fore-stomach were observed in rats) (IPCS 1989, 2002; BfR 2006 a \& b; IARC 2006). There is no evidence that formaldehyde is carcinogenic by the oral route (EFSA 2006). Formaldehyde causes toxicity to the nasal epithelium of rats and mice upon inhalation and induces above certain concentrations dose-related increases in nasal tumours. Epidemiological data have shown that formaldehyde is carcinogenic in human by the inhalation route (nasopharyngeal cancers and sinonasal cancers). While a genotoxic mode of action (MOA) can never be ruled out for a compound that is clearly genotoxic, at least in vitro and locally in vivo, the MOA would be based on the induction at the site of contact of sustained cytoxicity and cell proliferation upon long-term exposure (McGregor et al. 2006). 
Formaldehyde is produced industrially for a large number of applications such as the production of resins that act as adhesives and binders for wood products, pulp, paper, glass wool and rock wool, and the production of some plastics, coatings, paints and varnishes, industrial chemicals and textile finishing. It is also used in packaging, cosmetics and as a disinfectant and preservative. For example, formaldehyde is currently allowed as a preservative under the form of hexamethylene tetramine (E 239) in Provolone cheese at a residual concentration of $25 \mathrm{mg} / \mathrm{kg}$ expressed as formaldehyde (Directive 95/2/EC). For materials and articles made of plastic that come into contact with food, a specific migration limit (SML) of 15 $\mathrm{mg} / \mathrm{kg}$ is set for formaldehyde (Directive 2002/72/EC).

In the context of its monitoring programme, the Belgian Federal Agency for the Safety of the Food Chain (FASFC) analysed formaldehyde in cultivated mushrooms. In Belgium the use of formaldehyde as a disinfectant in the cultivation of mushrooms is not allowed. However, there are biocides admitted that contain formaldehyde and the regulation provides the possibility of exemptions for mushroom substrates and fertilisers (Royal Decree of January $7^{\text {th }}, 1998$ on the trade in fertilizers, soil improvers and growing substrates). Currently, there are no European nor Belgian standards for formaldehyde in mushrooms. The main objective of this paper is to evaluate if the presence of formaldehyde in cultivated mushrooms poses a risk to consumers and if regular control of formaldehyde in cultivated mushrooms is necessary. To place the potential risk into perspective, the total dietary exposure to formaldehyde is considered as well.

\section{Materials \& Methods}

\section{Samples}

A first batch of mushrooms (Agaricus, Pleurotus) was sampled in the context of the monitoring programme of the FASFC. Mainly mushrooms of Belgian origin were sampled, but also imported mushrooms were considered (Table 1). Next, an inquiry was performed at corresponding Belgian production sites, where a second mushroom sample (ready for harvesting), a sample of the compost bed and a sample of the casing soil were taken. Samples were stored frozen until analysis. 
Analysis of formaldehyde

Formaldehyde levels in mushrooms and substrates were analysed after extraction with acetonitrile and derivatization with dinitrophenylhydrazine (DNPH) by HPLC with ultra violet diode array detection (HPLC-UV-DAD, Varian, USA), according to the method described by 95 Tomkins et al. (1998).

For the extraction, fresh mushroom $(100 \mathrm{~g})$ was mixed with 1acetonitrile $(100 \mathrm{ml})$ and placed for $30 \mathrm{~min}$ in an ultrasonic bath and for $30 \mathrm{~min}$ on an orbital shaker. After filtration, $5 \mathrm{ml}$

DNPH derivatization reagent was added (i.e. $300 \mathrm{mg}$ DNPH dissolved in $50 \mathrm{ml}$ acetonitrile with $\left.0.5 \mathrm{ml} \mathrm{H}_{3} \mathrm{PO}_{4}(85 \%)\right)$. The mixture was further diluted to $200 \mathrm{ml}$ with acetonitrile and placed for 3 $\mathrm{h}$ in a thermostatic oven at $40^{\circ} \mathrm{C}$. After filtration on a membrane filter $(0.45 \mu \mathrm{m}), 20 \mu \mathrm{l}$ of sample was injected on a Luna C18 column (250 x $4.6 \mathrm{~mm}, 5 \mu \mathrm{m}$, Phenomenex). Mobile phase A was acetonitrile, mobile phase $\mathrm{B}$ was a $0.02 \mathrm{M} \mathrm{NaH}_{2} \mathrm{PO}_{4}$ solution in acetonitrile at $\mathrm{pH} 4(50: 50 \mathrm{v} / \mathrm{v})$.

103 Gradient elution started at $0 \%$ A, rising after 12 min linearly to $60 \%$ A over 2 min, held at $60 \%$ A 104 for a further 6 min before returning to the initial conditions. The total injection cycle time was 24 $105 \mathrm{~min}$ and the flow rate was $1.0 \mathrm{ml} / \mathrm{min}$. The presence of formaldehyde was confirmed by comparison of the samples' retention time $(\sim 9.6 \mathrm{~min})$ and characteristic spectrum with a standard sample (formaldehyde solution, > 36.5\%, Sigma-Aldrich) at $353 \mathrm{~nm}$. The limit of quantification (LOQ) for $100 \mathrm{~g}$ of sample was determined as $0.02 \mathrm{mg} / \mathrm{kg}$.

\section{Consumption data}

111 Consumption data were obtained from the Belgian Food Consumption Survey (BFCS) 112 performed in 2004 and coordinated by the Scientific Institute of Public Health (Devriese et al. 113 2005). The survey involved 3,214 participants older than 15 years, which were interviewed twice 114 about their consumption during the last 24 hours (non-consecutive $24 \mathrm{~h}$ recall). Participants were 115 selected by a multistage procedure from the National Register and the fieldwork was spread 116 over one year to anticipate seasonal effects. The usual food intake was estimated by the Nusser 117 method using C-side software (Dodd 1996). 
120 Results \& Discussion

121 Occurrence of formaldehyde

122 Formaldehyde is ubiquitous. Possible anthropogenic sources of formaldehyde are 123 combustion (vehicular exhaust, waste, cigarettes, etc.), industrial applications (resins, paints, 124 etc.) and consumer goods (cosmetics, pesticides, contact materials, etc.).

125 In the atmosphere, formaldehyde is both directly emitted and formed as a result of 126 photochemical oxidation of reactive organic gases. The concentration of formaldehyde in the air 127 is generally below $0.001 \mathrm{mg} / \mathrm{m}^{3}$ in rural areas and below $0.020 \mathrm{mg} / \mathrm{m}^{3}$ in urban areas (IARC 128 2006). The indoor air may contain higher levels of formaldehyde compared to the outdoor air 129 due to evaporation from furniture, paints and construction materials. Reported levels for indoor 130 air range between 0.02 and $0.06 \mathrm{mg} / \mathrm{m}^{3}$ (IARC 2006). The formaldehyde level due to 131 occupational exposure (e.g. during the varnishing of furniture and wooden floors, in the finishing 132 of textiles, in the garment industry, in the treatment of fur and in certain jobs within 133 manufactured board mills and foundries, ...) is on average $2 \mathrm{mg} / \mathrm{kg}$ (Heck \& Casanova 2004; 134 IARC 2006). In rainwater, formaldehyde concentrations of 0.1-0.2 mg/l are measured (IPCS 135 1998). In drinking water, formaldehyde is mainly formed by natural oxidation of humic 136 substances during the ozonation and chlorination of the water or is released into the water from 137 plastic plumbing. Water treated with ozone likely contains less than $50 \mu \mathrm{g}$ formaldehyde / I 138 (WHO 2005; Owen et al. 1990).

139 Formaldehyde is also naturally present in the majority of living organisms. As an 140 intermediary metabolic product formaldehyde is essential for the biosynthesis of certain amino 141 acids. In vivo most formaldehyde is probably (reversibly) bound to macromolecules (IPCS

142 2002). The content of endogenously metabolically formed formaldehyde can range between 3 143 and $12 \mathrm{ng} / \mathrm{g}$ tissue (Owen et al. 1990). The endogenous concentration of formaldehyde 144 measured in blood is 2-3 mg/l (IARC 2006). A similar concentration was found in the blood of 145 rats and monkeys (Heck et al. 1985; Casanova et al. 1988) and a 2 to 4 times higher 146 concentration was observed in the liver and the nasal mucosa of rats (Heck et al. 1982). 
147 Additionally, formaldehyde is a natural component of a variety of foodstuffs. Monitoring the 148 formaldehyde level of food however, has generally been performed sporadically and source149 directed and only few data are available to characterize the range and distribution of 150 formaldehyde concentrations in food (IPCS 2002). In the context of the monitoring programme, 151 the FASFC analysed the formaldehyde level of cultivated mushroom samples. The 152 concentration ranged between 0.08 and $0.65 \mathrm{mg} / \mathrm{kg}(n=29)$ (Table I). It seems that the 153 formaldehyde concentration of organically cultivated mushrooms (on average $0.34 \pm 0.19 \mathrm{mg} / \mathrm{kg}$ $154(n=5)$ ), is similar to the concentration measured in conventionally cultivated mushrooms (on 155 average $0.29 \pm 0.15 \mathrm{mg} / \mathrm{kg}(\mathrm{n}=24)$ ). (The production of organic food within the EU, as well as 156 the importation of organic food from outside the EU is controlled by EU Regulation 2092/91). No 157 correlation is observed between mushrooms and compost bed or casing soil with respect to the 158 formaldehyde concentration. Moreover, there seems to be no transfer of formaldehyde between 159 substrate treated with formaldehyde and mushrooms (internal communication, data not given). 160 At the production site no indications were found of unauthorized treatment of substrates 161 (compost bed and casing soil) with formaldehyde. Data given in Table I thus concerns 162 endogenously formed formaldehyde.

163 In literature studies considering the presence of formaldehyde in mushrooms are scarce.

164 Existing data concern Shiitake mushrooms, which have a relatively high formaldehyde level. In 165 a study of the British 'Food Safety Agency' (FSA) formaldehyde concentrations in the order of 166100 to $300 \mathrm{mg} / \mathrm{kg}$ were observed in both fresh and partially dried Shiitake mushrooms due to 167 natural production. These formaldehyde concentrations refer however, to a combination of free 168 and 'bound' formaldehyde (i.e. formaldehyde derived from the breakdown of larger molecules by 169 thermal degradation, by acidic and enzymatic hydrolyses, e.g. during analysis). After 6 minutes 170 of cooking, the formaldehyde level was significantly decreased. Preservation for 10 days had no 171 effect on the formaldehyde content of the mushrooms (Mason et al. 2004). In an opinion of the 172 French 'Agence Française de Sécurité Sanitaire des Aliments' (AFSSA), it was concluded that 173 a maximum formaldehyde level of $63 \mathrm{mg} / \mathrm{kg}$ in fresh Shiitake mushrooms can be considered 174 safe for the consumer (AFSSA 2001). Formaldehyde levels observed in the present study are 175 well below these values. 
177 [Table I]

For comparison, literature data regarding the formaldehyde concentration of different

180 foodstuffs are presented in Table II. Formaldehyde levels range between 3 and $60 \mathrm{mg} / \mathrm{kg}$ for

181 vegetables and fruits, between $<1$ and $34 \mathrm{mg} / \mathrm{kg}$ for fish and meat (for crustaceans between 1

182 and $98 \mathrm{mg} / \mathrm{kg}$ ), and around $1 \mathrm{mg} / \mathrm{kg}$ for milk and milk products. For alcoholic beverages, soft

183 drinks and coffee, formaldehyde levels between 0.02 and $16.3 \mathrm{mg} / \mathrm{L}$ are reported. It should be

184 noted however, that literature data are scarce and that data presented in Table II could be 185 biased (e.g. because they are based on a limited number of samples). Most of the levels 186 reported in Table II are due to the natural occurrence of formaldehyde, but it can not be 187 excluded that some values are a result of processing (e.g. fumigation, the use of formaldehyde188 containing food additives, migration from melamine-, phenol- and urea-formaldehyde plastics, 189 addition to feed to improve handling characteristics or as a preservative, etc.). Moreover, the 190 analytical method used to quantify formaldehyde may affect the formaldehyde level measured 191 since there are many potential precursors that can form formaldehyde under certain extraction 192 and derivatization conditions used during analysis (Mason et al. 2004).

194 [Table II]

196 Formaldehyde intake

197 Table III presents the intake of formaldehyde through the consumption of cultivated mushrooms 198 based on monitoring data of the FASFC (Table I) and consumption data of the BFCS (IPH 199 2006). The intake was calculated by a deterministic approach multiplying a fixed value for 200 consumption with a fixed value for the formaldehyde level (such as the mean or P97.5), and 201 concerns only consumers of mushrooms and not the whole population. One of the main 202 criticisms of the deterministic approach is its inherent conservatism. Nevertheless, due to its 203 simplicity and its worldwide use and acceptance, this point estimate approach may be used as a 204 screening tool. 
205 On average, the formaldehyde intake due to the consumption of cultivated mushrooms was $2060.2 \mu \mathrm{g} / \mathrm{kg}$ bw per day. In the (upper) worst case scenario, the intake could amount to $4.0 \mu \mathrm{g} / \mathrm{kg}$ 207 bw per day. In the FSA study cited above, the formaldehyde intake due to consumption of 208 Shiitake mushrooms was estimated to be $0.15-0.16 \mathrm{mg} / \mathrm{kg} \mathrm{bw}$. It was concluded that such an 209 intake level poses probably no appreciable risk to public health (Mason et al. 2004). The intake 210 determined in the FSA study is two orders of magnitude higher than estimated in the present 211 study. Not only different types of mushrooms were considered in both studies, but also different 212 analytical methods were applied. As mentioned above, the analytical conditions used can affect 213 the formaldehyde level measured due to the breakdown by thermal degradation, acidic and 214 enzymatic hydrolyses of larger molecules. In the FSA study, formaldehyde levels were 215 determined after extraction by acid hydrolysis and steam distillation using a spectrophotometric 216 method and LC-MS. Formaldehyde formation and potential routes for its generation in 217 mushrooms by steam distillation under acidic conditions have been described in literature 218 (Tyihak et al. 1996 and Yamazaki et al. 1980, cited by Mason et al.2004).

220 [Table III]

Additionally the total dietary exposure of formaldehyde was estimated deterministically for 223 the whole population (Table IV). Based on the formaldehyde data available in literature, an 224 average formaldehyde intake of approximately $7.5 \mathrm{mg} / \mathrm{day}(0.10 \mathrm{mg} / \mathrm{kg}$ bw per day) was 225 obtained (beverages not included). This is a rough estimate of the actual intake, for one 226 because it was assumed that each person consumes each day average amounts of fruit, 227 vegetables, meat or fish, milk and dairy products. Also, formaldehyde levels used for 228 calculations were taken arbitrary as the average between the minimum and maximum 229 concentration found in literature and are as such biased (see supra). In addition, the effect of 230 e.g. cooking before consumption on the formaldehyde content, which can lower the 231 formaldehyde content of the food by evaporation, was not accounted for. Moreover, the 232 proportion of formaldehyde in foods that is bioavailable and the amount that is in a bound and 233 unavailable form, is unknown (IPCS 1989, 2002; Health Canada 2001). 
A similar exercise was performed by Owen et al. (1990), who calculated an annual dietary 235 formaldehyde intake of about $4000 \mathrm{mg} / \mathrm{year}$, equivalent to approximately $11 \mathrm{mg} /$ day. The intake 236 through drinking water was calculated to be on average less than $40 \mu \mathrm{g} / \mathrm{day}$. The rough 237 estimate given by the 'International Programme on Chemical Safety' (IPCS 1989) for 238 formaldehyde exposure through food is of the same range, namely between 1.5 to $14 \mathrm{mg} / \mathrm{day}$ 239 for an average adult.

240 It is clear that the intake through the consumption of mushrooms is negligible compared to 241 the intake of formaldehyde via the consumption of different food products (only $0.2 \%$ ).

243 [Table IV]

When considering the 'total' exposure to formaldehyde, also other routes of exposure 246 should be considered such as inhalation and skin absorption by dermal contact (e.g. by use of 247 cosmetics). The latter route of exposure can be considered negligible (except in certain 248 workplaces) whereas the first route is probably the most important one. Probabilistic simulations 249 of Health Canada indicate that through air one of every two persons would be exposed to 24-h 250 average formaldehyde concentrations of $\geq 20-24 \mu \mathrm{g} / \mathrm{l}\left(24-29 \mu \mathrm{g} / \mathrm{m}^{3}\right)$ and that 1 in 20 persons 251 (i.e. the $95^{\text {th }}$ percentile) would be exposed to $24-\mathrm{h}$ average formaldehyde concentrations in air $\geq$ 252 67-78 $\mathrm{\mu g} / \mathrm{l} \quad\left(80-94 \mu \mathrm{g} / \mathrm{m}^{3}\right)$ (Health Canada 2001). The German 'Bundesinstitut für 253 Risikobewertung' (BfR) established in a recent toxicological evaluation a tolerable air 254 concentration of $0.1 \mathrm{mg} / \mathrm{l}$ formaldehyde, which is in line with the MAC value or 'Maximum 255 Allowable Concentration' of $0.3 \mathrm{mg} / \mathrm{l}$ determined to protect workers in the workplace (BfR 256 2006b).

\section{Risk Characterization}

259 The WHO guideline for drinking water sets a maximum limit of $900 \mu \mathrm{g}$ formaldehyde/l water 260 (WHO 2006). The limit was determined on the basis of a TDI ('tolerable daily intake') of 0.15 $261 \mathrm{mg} / \mathrm{kg}$ bw per day and assuming that drinking water accounts for $20 \%$ of the intake. This TDI 262 was established on the basis of a NOAEL ('no observed adverse effect level') of $15 \mathrm{mg} / \mathrm{kg} \mathrm{bw}$ 
263 per day from a 2-year study in rats where irritations of the stomach and papillary hyperplasia 264 were observed at a formaldehyde dose of $82 \mathrm{mg} / \mathrm{kg}$ bw per day. Based on the same NOAEL the 265 U.S. Environmental Protection Agency (EPA) determined a chronic reference dose (RfD) of 0.2 $266 \mathrm{mg} / \mathrm{kg}$ bw per day for oral exposure (U.S. EPA 1990). The formaldehyde intake through 267 consumption of mushrooms estimated in this study is $0.10 \%$ of the chronic U.S. EPA RfD and $2680.13 \%$ of the TDI determined by the WHO. As to the total dietary intake, it amounts to more or 269 less $50 \%$ and $66 \%$ of the U.S. EPA and WHO safety limits respectively.

270 The risk associated with the formaldehyde levels measured in food appears thus to be 271 acceptable. Moreover, in an opinion regarding the use of formaldehyde as a preservative in food 272 manufacturing the EFSA AFC Panel ('Panel on food additives, flavourings, processing aids and 273 materials in contact with food') concluded on the basis of recent and past toxicological 274 evaluations that there is no evidence indicating that formaldehyde is carcinogenic by the oral 275 route (EFSA 2006).

\section{Conclusion}

278 The levels of formaldehyde detected in cultivated mushrooms are generally lower than the 279 levels reported to occur naturally in vegetables, fruit, meat, fish and dairy products. The 280 consumption of mushrooms results in a formaldehyde intake 1000 times lower than the 281 toxicological safety limits given by the WHO and the U.S. EPA and contributes only little to the 282 total formaldehyde intake. Regular control of formaldehyde in cultivated mushrooms is thus not 283 a priority.

284 Due to a lack of data, it is difficult to assess precisely the total dietary intake. Nevertheless, 285 the rough estimate presented in this paper is in line with values reported elsewhere and is $66 \%$ 286 of the WHO TDI of $0.15 \mathrm{mg} / \mathrm{kg}$ bw per day. Since probably not all formaldehyde is bioavailable 287 and since there are no indications that formaldehyde is carcinogenic via the oral route, it can be 288 concluded that the natural occurrence of formaldehyde in food presents no immediate cause for 289 concern. 
290

291 Acknowledgement

292 The authors like to acknowledge the Scientific Committee of the Belgian Federal Agency for 293 the Safety of the Food Chain for their guidance of this study. 


\section{References}

295

297 [internet]. January 2004. France: Agence française de la Sécurité Sanitaire des Aliments; [cited: 2008 Oct 298 6]. Available from: http://www.afssa.fr/Documents/ALAN-Ra-formaldehyde.pdf

299 AFSSA. 2001. Avis de l'Agence française de sécurité sanitaire des aliments relatif à un projet 300 d'arrêté relatif à la teneur maximale en formaldéhyde que doivent présenter les champignons de l'espèce 301 shiitaké (Lentinus edodes) [internet]. September 24, 2001. France: Agence française de la Sécurité 302 Sanitaire des Aliments; [cited: 2008 Oct 6]. Available from:

\section{3 http://www.afssa.fr/Documents/AAAT2001sa0228.pdf}

304 BfR. 2006a. Schulte A, Bernauer U, Madle S, Mielke H, Herbst U, Richter-Reichhelm H-B, Appel K-E

$305 \&$ \& Gundert-Remy U. Assessment of the carcinogenicity of formaldehyde [CAS No. 50-00-0] [internet].

306 February 2006. Germany: Bundesinstitut für Risikobewertung; [cited: 2008 Oct 6]. Available from:

307 http://www.bfr.bund.de/cm/238/assessment of the carcinogenicity of formaldehyde.pdf

308 BfR. 2006b. Toxicological assessment of formaldehyde. Opinion of BfR No. 023/2006 [internet].

309 March 30, 2006. Germany: Bundesinstitut für Risikobewertung; [cited: 2008 Oct 6]. Available from:

310 http://www.bfr.bund.de/cm/290/toxicological assessment of formaldehyde.pdf

311 Casanova M, Heck H d'A, Everitt J, Harrington Jr W, Popp J. 1988. Formaldehyde concentrations in 312 the blood of rhesus monkeys after inhalation exposure. Food Chem Toxicol. 26: 715-716.

313 CFS. 2008. Yau A. - Formaldehyde in food [internet]. April 2008. Hong Kong: Centre for Food Safety

314 - The Government of the Hong Kong Special Administrative Region; [cited: 2008 Oct 6]. Available from:

315 http://www.cfs.gov.hk/english/multimedia/multimedia pub/multimedia pub fsf 06 01.html

316 Commission Directive 2002/72/EC of 6 August 2002 relating to plastic materials and articles intended

317 to come into contact with foodstuffs. Off J. L 220, 15/8/2002, p.18.

318 Commission Directive 2001/59/EC of 6 August 2001 adapting to technical progress for the 28th time

319 Council Directive 67/548/EEC on the approximation of the laws, regulations and administrative provisions

320 relating to the classification, packaging and labelling of dangerous substances. Off J. L 225, 21/08/2001, 321 p.1.

322 Commission Directive 95/2/EC of 20 February 1995 on food additives other than colours and 323 sweeteners. Off J. L 61, 18/3/1995, p.1.

324 Council Regulation (EEC) No 2092/91 of 24 June 1991 on organic production of agricultural products 
325 and indications referring thereto on agricultural products and foodstuffs.Devriese S, De Backer G, De 326 Henauw S, Huybrechts I, Kornitzer K, Leveque A, Moreau M, Van Oyen H. 2005. The Belgian food 327 consumption survey: Aims, design and methods. Arch Public Health 63: 1-16.

328 Dodd K. 1996. A technical guide to C-SIDE. Software for Intake Distribution Estimation. Technical 329 Report 96-TR 32, 1-68. Department of Statistics and Center for Agricultural and Rural Development; lowa 330 State University.

331 EFSA. 2006. Opinion of the Scientific Panel on food additives, flavourings, processing aids and materials 332 in contact with food (AFC) on a request from the Commission related to the use of formaldehyde as a 333 preservative during the manufacture and preparation of food additives (Question № EFSA Q-2005-032). 334 The EFSA Journal 415: 1-10. [cited: 2008 Oct 6]. Available from: 335 http://www.efsa.europa.eu/EFSA/Scientific Opinion/afc op ej415 formaldehyde op en,2.pdf

FSA. 1998. MAFF UK - Survey of chemical migration from can coatings into food and beverages 1, Formaldehyde [internet]. September 1998. UK: Food Safety Agency; [cited: 2008 Oct 6]. Available from: http://archive.food.gov.uk/maff/archive/food/infsheet/1998/no157/157form.htm\#ref2

Hayashi T, Reece CA, Shibamoto T. 1986. Gas Chromatographic determination of formaldehyde in 341 coffee via thiazolidine derivative. J Assoc Off Anal Chem. 69: 101-105.

342 Health Canada. 2008. Environmental and Workplace Health. Health-based guidance values for 343 substances on the second priority substances list. 3.3 Estimates of exposure to PSL2 substances 344 [internet]. February 2008. Canada: Health Canada; [cited: 2008 Oct 6]. Available from: http://www.hc345 sc.gc.ca/ewh-semt/pubs/contaminants/value-valeur/table-tableau-3-eng.php

346 Health Canada. 2001. Canadian environmental protection act, 1999. Priority substances list 347 assessment report. Formaldehyde [internet]. February 2001. Canada: Health Canada; [cited: 2008 Oct 6]. 348 Available from: http://www.hc-sc.gc.ca/ewh-semt/alt formats/hecs-sesc/pdf/pubs/contaminants/psl2349 Isp2/formaldehyde/formaldehyde-eng.pdf

350 Heck H d'A, Casanova-Schmitz M, Dodd P, Schachter E, Witek T, Tosun T. 1985. Formaldehyde $351(\mathrm{CH} 2 \mathrm{O})$ concentrations in the blood of humans and Fischer-344 rats exposed to $\mathrm{CH} 2 \mathrm{O}$ under controlled 352 conditions. Am Ind Hyg Assoc J. 46: 1-3.

353 Heck H d'A, Casanova M. 2004. The implausibility of leukemia induction by formaldehyde: A critical 354 review of the biological evidence on distant-site toxicity. Regul Toxicol Pharmacol. 40: 92-106.

355 Heck H d'A, White E, Casanova-Schmitz M. 1982. Determination of formaldehyde in biological 356 tissues by gas chromatography/mass spectrometry. Biomed Mass Spectrom. 9: 347-353. 
357 IARC. 2006. Formaldehyde, 2-butoxyethanol and 1-tert-Butox-2-propanol. IARC Monographs on the 358 evaluation of carcinogenic risks to humans. 88: 2-9 [internet]. 2006. Franc: IARC; [cited: 2008 Oct 6]. 359 Available from: $\underline{\text { http://monographs.iarc.fr/ENG/Monographs/vol88/mono88.pdf }}$

360 IPCS. 2002. International Programme on Chemical Safety. Formaldehyde. Concise international 361 chemical assessment document [internet]. 2002. Stuttgart, Germany: WHO; [cited: 2008 Oct 6]. Available 362 from: http://www.inchem.org/documents/cicads/cicads/cicad40.htm

363 IPCS. 1989. International Programme on Chemical Safety, Formaldehyde. Environmental Health 364 Criteria, Geneva, 219 p [internet]. 1989. Geneva, Switzerland: WHO; [cited: 2008 Oct 6]. Available from: 365 http://www.inchem.org/documents/ehc/ehc/ehc89.htm

366 Larsen P. 1998 Toxicological evaluation and limit values for methyl-tertiary-butyl ether (MTBE), 367 formaldehyde, glutaraldehyde, furfural. pp. $31-39$ [internet]. February 1998. Denmark: Danish Veterinary 368 and Food Administration - The Institute of Food Safety and Toxicology; [cited: 2008 Oct 6]. Available from: 369 http://www2.mst.dk/udgiv/Publications/1999/87-7909-563-1/pdf/87-7909-562-3.PDF

370 Lawrence J, lyengar J. 1983 The determination of formaldehyde in beer and soft drinks by HPLC of 371 the 2,4-dinitrophenylhydrazone derivative. Intern J Environ Anal Chem. $15:$ 47-52.

372 Mason DJ, Sykes MD, Panton SW, Rippon EH. 2004. Determination of naturally-occuring 373 formaldehyde in raw and cooked Shiitaki mushrooms by spectrophotometry and liquid chromatography374 mass spectrometry. Food Add Cont. 21: 1071-1082.

375 McGregor D, Bolt H, Cogliano V, Richter-Reichhelm HB. 2006. Formaldehyde and glutaraldehyde 376 and nasal cytotoxicity: Case study within the context of the 2006 IPCS human framework for the analysis 377 of a cancer mode of action for humans. Crit Rev Toxicol. 36: 821-835.

378 Owen BA, Dudney CS, Tan EL, Easterly CE. 1990. Formaldehyde in drinking water: Comparative 379 hazard evaluation and an approach to regulation. Regul Toxicol Pharmacol. 11: 20-236.

380 Soffritti M. Maltoni C, Maffei F, Biagi R. 1989. Formaldehyde: an experimental multipotential 381 carcinogen. Toxicol Ind Health. 5: 699-730.

382 Soffritti M, Belpoggi F, Lambertin L, Lauriola M, Padovani M, Maltoni C. 2002. Results of long-term 383 experimental studies on the carcinogenicity of formaldehyde and acetaldehyde in rats. Ann NY Acad Sci. $384982: 87-105$.

385 Tomkins BA, McMahon JM, Caldwell WM, Wilson DL. 1989 Liquid chromatographic determination of 386 total formaldehyde in drinking water. J Assoc Off Anal Chem. 72: 835-839.

387 US EPA. 1990. Integrated Risk Information System (IRIS) - Formaldehyde [internet]. January 1990. 388 US: Environmental Protection Agency; [cited: 2008 Oct 6]. Available from: 
389 http://www.epa.gov/iris/subst/0419.htm

390

391 WHO. 2006. Guidelines for drinking-water quality. Third Edition. p. 194 [internet]. Geneva, 392 Switzerland: World Health Organisation; [cited: 2008 Oct 6]. Available from: 393 http://www.who.int/water sanitation health/dwq/gdwq3/en/

394 WHO. 2005. Formaldehyde in drinking-water. Background document for development of WHO 395 Guidelines for drinking-water quality. Geneva, World Health Organization (WHO/SDE/WSH/05.08/48) 396 [internet]. Geneva, Switzerland: World Health Organisation; [cited: 2008 Oct 6]. Available from: 397 http://www.who.int/water sanitation health/dwq/chemicals/formaldehyde130605.pdf 
1 Table I. Formaldehyde concentration $(\mathrm{mg} / \mathrm{kg}$ ) measured in cultivated mushrooms, compost bed

2 and casing soil.

3

\begin{tabular}{|c|c|c|c|c|}
\hline $\begin{array}{c}\text { Mushroom } \\
\text { sample } 1\end{array}$ & $\begin{array}{c}\text { Mushroom } \\
\text { sample } 2\end{array}$ & $\begin{array}{c}\text { Compost } \\
\text { bed }\end{array}$ & Casing soil & Remarks \\
\hline 0.35 & 0.40 & 0.23 & 0.02 & Belgian origin, Conventional farming \\
\hline 0.27 & 0.08 & 0.10 & $<\operatorname{LOQ}(0.02)$ & Belgian origin, Conventional farming \\
\hline 0.31 & 0.13 & 0.36 & 0.02 & Belgian origin, Conventional farming \\
\hline 0.30 & 0.21 & 0.12 & 0.05 & Belgian origin, Conventional farming \\
\hline \multirow[t]{3}{*}{0.21} & 0.53 & 0.49 & 0.06 & Belgian origin, Organic farming \\
\hline & 0.56 & 0.49 & 0.06 & Belgian origin, Organic farming \\
\hline & 0.16 & 0.28 & & Belgian origin, Organic farming \\
\hline 0.39 & 0.38 & 0.44 & 0.04 & Belgian origin, Conventional farming \\
\hline 0.42 & & & & Belgian origin, Conventional farming \\
\hline 0.53 & 0.18 & 0.05 & 0.02 & Belgian origin, Conventional farming \\
\hline \multirow[t]{3}{*}{0.21} & & & & Belgian origin, Conventional farming \\
\hline & 0.18 & 0.27 & 0.03 & Belgian origin, Conventional farming \\
\hline & 0.30 & 0.20 & 0.03 & Belgian origin, Conventional farming \\
\hline 0.16 & 0.07 & 0.34 & & $\begin{array}{l}\text { Belgian origin, Conventional farming; } \\
5.1 \mathrm{mg} \text { formaldehyde / } \mathrm{kg} \text { was } \\
\text { measured in supplementary feeding }\end{array}$ \\
\hline 0.18 & 0.09 & 0.30 & & Belgian origin, Conventional farming \\
\hline 0.65 & & & & Belgian origin, Conventional farming \\
\hline 0.24 & & & & Dutch origin, Organic farming \\
\hline 0.28 & & & & Polish origin, Conventional farming \\
\hline 0.34 & & & & Polish origin, Conventional farming \\
\hline 0.45 & & & & Polish origin, Conventional farming \\
\hline
\end{tabular}


5 Table II. Formaldehyde level of different foodstuffs reported in literature .

\begin{tabular}{|c|c|c|c|}
\hline Food & $\begin{array}{c}\text { Concentration } \\
\mathrm{mg} / \mathrm{kg} \text { (litre) }\end{array}$ & Remarks & Ref. \\
\hline \multicolumn{4}{|l|}{ Fruit \& vegetables } \\
\hline \multirow[t]{2}{*}{ Apples } & $17.3(38.7)^{a}$ & $\begin{array}{l}\text { Colorimetric determination using chromotropic } \\
\text { acid (Schiff 's reagent) }\end{array}$ & (1) \\
\hline & $6.3-22.3$ & & (2) \\
\hline Banana & 16.3 & & (2) \\
\hline Pears & $60(38.7)^{a}$ & $\begin{array}{l}\text { Colorimetric determination using chromotropic } \\
\text { acid (Schiff 's reagent) }\end{array}$ & (1) \\
\hline Cauliflower & $4.7(5.3)^{a}$ & $\begin{array}{l}\text { Colorimetric determination using chromotropic } \\
\text { acid (Schiff 's reagent) }\end{array}$ & (1) \\
\hline Carrots & $\begin{array}{c}26.9 \\
6.7(10)^{a}\end{array}$ & $\begin{array}{l}\text { Colorimetric determination using chromotropic } \\
\text { acid (Schiff 's reagent) }\end{array}$ & $\begin{array}{l}(2) \\
(1)\end{array}$ \\
\hline Onion & $13.3(26.3)^{\mathrm{a}}$ & $\begin{array}{l}\text { Colorimetric determination using chromotropic } \\
\text { acid (Schiff 's reagent) }\end{array}$ & (1) \\
\hline Spinach & $3.3(7.3)^{a}$ & $\begin{array}{l}\text { Colorimetric determination using chromotropic } \\
\text { acid (Schiff 's reagent) }\end{array}$ & (1) \\
\hline Tomatoes & $5.7(7.3)^{a}$ & $\begin{array}{l}\text { Colorimetric determination using chromotropic } \\
\text { acid (Schiff 's reagent) }\end{array}$ & (1) \\
\hline Radish & $3.7(4.4)^{\mathrm{a}}$ & $\begin{array}{l}\text { Colorimetric determination using chromotropic } \\
\text { acid (Schiff 's reagent) }\end{array}$ & (1) \\
\hline Shiitake mushrooms & $\begin{array}{c}100-406 / 6-54.4 \\
100-320\end{array}$ & $\begin{array}{l}\text { Colorimetric determination using chromotropic } \\
\text { acid and dimedone/ammonium acetate } \\
\text { derivative measured by LC-MS/MS }\end{array}$ & $\begin{array}{l}(2) \\
(3)\end{array}$ \\
\hline \multicolumn{4}{|l|}{ Meat products } \\
\hline Beef & $\begin{array}{c}0.094 \pm 0.044 \\
0.079 \pm 0.051 \text { and } \\
0.161 \pm 0.071\end{array}$ & $\begin{array}{l}\text { France } \\
\text { European Member States }\end{array}$ & $\begin{array}{l}(4) \\
(4)\end{array}$ \\
\hline Poultry & $\begin{array}{c}5.7 \\
2.3-5.7\end{array}$ & Colorimetric analysis & $\begin{array}{l}(1) \\
(4)\end{array}$ \\
\hline Pork & 20 & $\begin{array}{l}\text { Colorimetric determination using chromotropic } \\
\text { acid }\end{array}$ & (1) \\
\hline $\begin{array}{l}\text { Sheep } \\
\text { Beef, pork, sheep } \\
\text { and chicken }\end{array}$ & $\begin{array}{c}8 \\
2.5-20\end{array}$ & & $\begin{array}{l}(1) \\
(2)\end{array}$ \\
\hline Fish products & & & (1) \\
\hline Freshwater fish & 8.8 & Fumigated, colorimetric analysis & (1) \\
\hline Sea fish & 20 & Fumigated, colorimetric analysis & (1) \\
\hline Cod & $\begin{array}{c}20 \\
4.6-34\end{array}$ & Frozen & $\begin{array}{l}(1) \\
(2)\end{array}$ \\
\hline \multirow[t]{2}{*}{ Crustaceans } & $1-60$ & Mediterranean & (1) \\
\hline & $3-98$ & Ocean & (1) \\
\hline \multirow[t]{2}{*}{ Shrimp } & 1 & Live, HPLC & (1) \\
\hline & \multicolumn{3}{|c|}{ Milk \& dairy products } \\
\hline Milk & $0.041 \pm 0.045$ & France & (4) \\
\hline Goat's milk & 1 & & (1) \\
\hline Cow's milk & Up to3.3 & Colorimetric analysis & (1) \\
\hline Fresh milk & $0.013-0.057$ & $($ mean $=0,027 \mathrm{mg} / \mathrm{l})$ & (5) \\
\hline Treated milk & $0.075-0.255$ & $($ mean $=0,164 \mathrm{mg} / \mathrm{l})$ & (5) \\
\hline Cheese & up to 3.3 & Colorimetric analysis & (1) \\
\hline Dairy products & 0.02 & & (4) \\
\hline \multicolumn{4}{|l|}{ Beverages } \\
\hline \multirow[t]{2}{*}{ Alcoholic beverages } & $0.04-1.7$ & $\begin{array}{l}\text { Fluorescence detection after on-line } \\
\text { condensation with 4-amino-3-penten-2-one } \\
\text { (Japan) }\end{array}$ & (5) \\
\hline & $0.02-3.8$ & Spectrofluorimetric determination (Brazil) & (5) \\
\hline
\end{tabular}


1

2

3

4

5

6

7

8

9

10

11

12

13

14

15

16

17

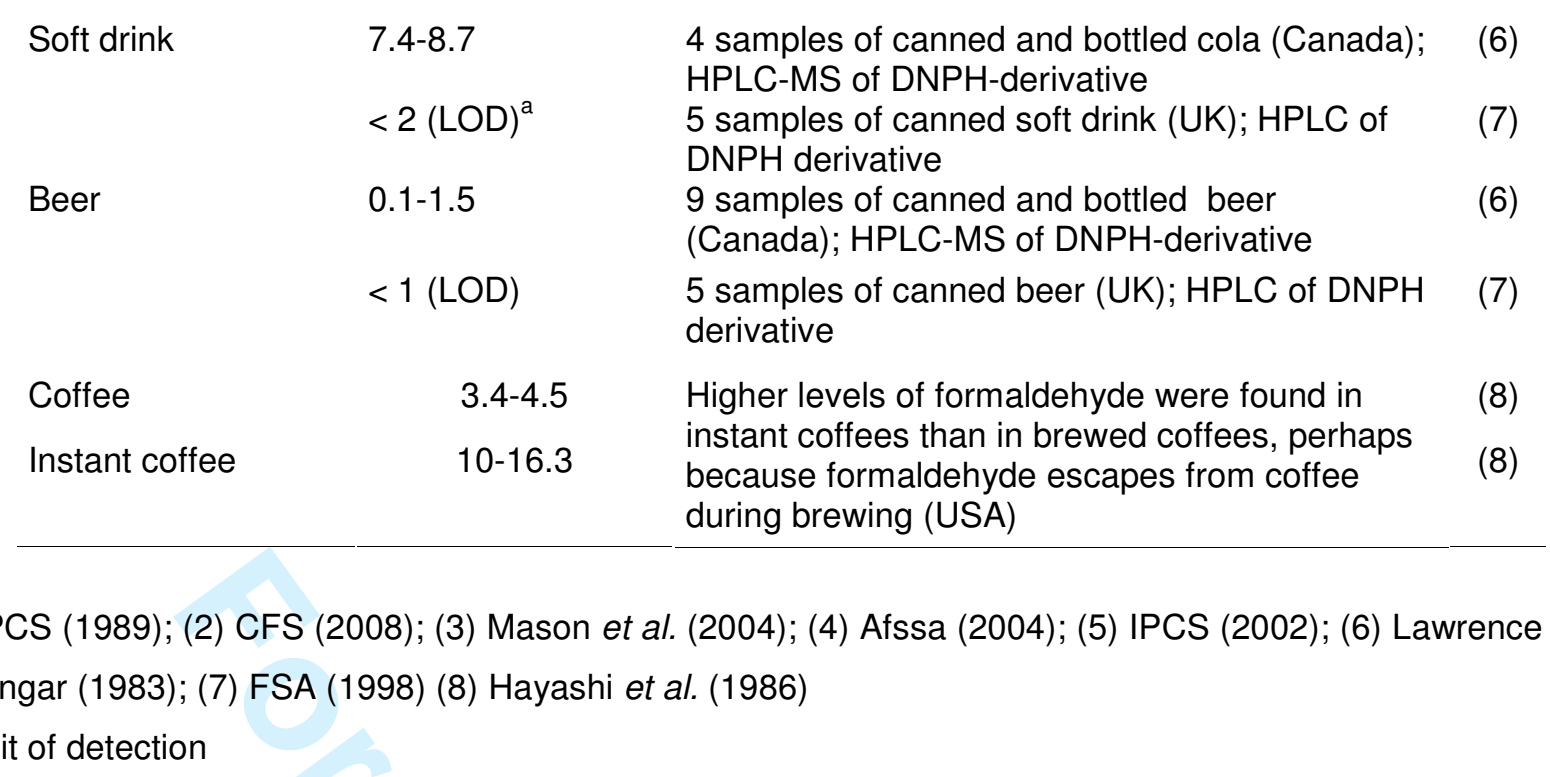


11 Table III. Intake of formaldehyde by the consumption of mushrooms.

12

\begin{tabular}{|c|c|c|c|c|}
\hline & [Formaldehyde] $^{1}$ & Consumption $^{2}$ & & $\operatorname{Intake}^{3}$ \\
\hline & $\mathrm{mg} / \mathrm{kg}$ & g/day & $\mathrm{mg} /$ day & $\mu \mathrm{g} / \mathrm{kg}$ bw per day \\
\hline Mean & 0.288 & 49 & 0.01 & 0.19 \\
\hline P50 & 0.275 & 34 & 0.01 & 0.12 \\
\hline P95 & 0.547 & 160 & 0.09 & 1.15 \\
\hline P97,5 & 0.585 & 200 & 0.12 & 1.54 \\
\hline P99 & 0.624 & 233 & 0.15 & 1.91 \\
\hline $\mathrm{P} 100$ & 0.650 & 465 & 0.30 & 3.98 \\
\hline
\end{tabular}

13

$14{ }^{1} 29$ samples, see Table I

$15{ }^{2}$ usual consumption of the Belgian population ('consumers only') -460 consumption days (Devriese et 16 al. 2005)

$17{ }^{3}$ calculated deterministically; the body weight was assumed to be $76 \mathrm{~kg}$ 
18 Table IV. Formaldehyde intake by the consumption of different foodstuffs.

19

\begin{tabular}{lcccc}
\hline & [Formaldehyde] $^{1}$ & $\begin{array}{c}\text { Average }^{2} \\
\text { consumption }^{2}\end{array}$ & \multicolumn{2}{c}{ Intake $^{3}$} \\
\hline & $\mathrm{mg} / \mathrm{kg}$ & $\mathrm{g} / \mathrm{day}$ & $\mathrm{mg} /$ day & $\begin{array}{c}\mu \mathrm{g} / \mathrm{kg} \mathrm{bw} \mathrm{per} \\
\text { day }\end{array}$ \\
\hline Vegetables & & & \\
Fruit & 15.1 & 138.3 & 2.1 & 27.48 \\
Meat & 33.2 & 118.2 & 3.9 & 51.56 \\
Fish and seafood & 10.0 & 120.7 & 1.2 & 15.92 \\
Milk and dairy & 49.5 & 23.9 & 1.2 & 15.57 \\
beverages & 1.7 & 90.6 & 0.2 & 1.97 \\
Cheese & 1.7 & 30.2 & 0.1 & 0.66 \\
Yoghurt and pudding & 1.7 & 63.1 & 0.1 & 1.38 \\
\hline
\end{tabular}

${ }^{1}$ concentration = average of minimum and maximum concentration reported (Table II); it was assumed

21 that preparation of food (e.g. cooking) did not reduce the formaldehyde concentration

$22{ }^{2}$ usual average consumption of the Belgian population (Devriese et al. 2005)

$23{ }^{3}$ calculated deterministically; the body weight was assumed to be $76 \mathrm{~kg}$

$24{ }^{4}$ Shiitake mushrooms excluded 